ISTIGHNA, Vol. 3, No 2, Juli 2020 P-ISSN 1979-2824 E-ISSN 2655-8459

Homepage: http://e-journal.stit-islamic-village.ac.id/index.php/istighna

Siti Aisyah, Rini Setyaningsih

Hubungan antara Profesionalitas Tenaga Pendidik dengan Mutu Pendidikan di Madrasah Aliyah Negeri 1 Pekanbaru

\title{
HUBUNGAN ANTARA PROFESIONALITAS TENAGA PENDIDIK DENGAN MUTU PENDIDIKAN DI MADRASAH ALIYAH NEGERI 1 PEKANBARU
}

\author{
Siti Aisyah \\ aisyahabdullahnst@gmail.com \\ Universitas Islam Negeri Sultan Syarif Kasim Riau \\ Rini Setyaningsih \\ rinisetyaningsih@gmail.com \\ Universitas Islam Negeri Sultan Syarif Kasim Riau
}

\begin{abstract}
It was a correlational research studying about educator professionality ( $\mathrm{X}$ variable) and education quality (Y variable) at State Islamic Senior High School 1 Pekanbaru. This research aimed at knowing educator professionality level, education quality level, and the correlation between educator professionality and education quality at State Islamic Senior High School 1 Pekanbaru. The samples were 46 educators at State Islamic Senior High School 1 Pekanbaru that met the requirements of professional educators - educator competence, qualification of education, and certification. The data were analyzed by using Pearson product moment correlational formula. Based on the analysis, it showed that $\mathrm{H}_{0}$ was rejected and $\mathrm{H}_{\mathrm{a}}$ was accepted. It meant that there was a positive and significant correlation between educator professionality and education quality at State Islamic Senior High School 1 Pekanbaru. It could be seen from the comparison between $r_{\text {observed }} 0.694$ and $r_{\text {table }} 0.361$ at $5 \%$ significant level with $N$ that was 46 , so $r_{\text {observed }}$ was higher than $r_{\text {table }}(0.694>0.361)$. The result of linear regression coefficient showed that the probability score or the significance score 0.000 was lower than $0.05(0.000<0.05)$. Based on the determination coefficient, it was obtained the score 0.482 or $48.2 \%$ and it was rounded up to $48 \%$. It meant that the contribution of educator professionality variable to education quality variable at State Islamic Senior High School 1 Pekanbaru was $48 \%$, and the rest was influenced by other variables that were not explained in this research. So, the professional educators could increase the quality of education.
\end{abstract}

Keywords: Correlation, Educator Professionality, Education Quality

Abstrak: Penelitian ini merupakan penelitian korelasional yang mengkaji tentang
Profesionalitas Tenaga Pendidik (Variable X) dengan Mutu Pendidikan (Varibel
Y) di madrasah Aliyah Negeri 1 Pekanbaru. Penelitian ini bertujuan untuk
mengetahui tingkat profesionalitas tenaga pendidik, tingkat mutu pendidikan, dan
hubungan profesionalitas tenaga pendidik dengan mutu pendidikan. Sampel yang
digunakan dalam penelitian ini adalah tenaga pendidik di Madrasah Aliyah Negeri
1 Pekanbaru yang berjumlah 46 orang tenaga pendidik yang telah memenuhi
persyaratan tenaga pendidik profesional yang terdiri dari komptensi tenaga
pendidik, kualifikasi pendidikan, sertifikasi. Data penelitian ini dianalisis dengan

Peer reviewed under reponsibility of STIT ISLAMIC VILLAGE.

(C) 2018 STIT ISLAMIC VILLAGE, All right reserved, This is an open access article under 158

the CC BY SA license (https://creativecommons.org/licenses/by-sa/4.0/) 
ISTIGHNA, Vol. 3, No 2, Juli 2020 P-ISSN 1979-2824

Homepage: http://e-journal.stit-islamic-village.ac.id/index.php/istighna

Siti Aisyah, Rini Setyaningsih Hubungan antara Profesionalitas Tenaga Pendidik dengan Mutu Pendidikan di Madrasah Aliyah Negeri 1 Pekanbaru

rumus korelasi Product Moment Pearson. Berdasarkan hasil uji analisis menunjukan bahwa $H_{0}$ tolak dan $H_{a}$ diterima. Artinya terdapat hubungan yang positif dan signifikan antara profesionalitas tenaga pendidik dengan mutu pendidikan di Madrasah Aliyah Negeri 1 Pekanbaru. Hal ini dapat dilihat dari perbandingan $r_{\text {hitung }}$ sebesar 0.694 dan $r_{\text {tabel }} 0,361$ dengan $N=46$ pada taraf signifikan 5\% sebesar 0.361, jadi $r_{\text {hitung }}$ lebih besar dari $r_{\text {tabel }}(0.694>0,361)$. Hasil data pada koefesiensi regresi linear menunjukkan nilai probabilitas atau nilai signifikan 0.000 dan lebih kecil dari 0.05 (0.000<0.05). Berdasarkan koefisien determinasi diperoleh nilai 0.482 atau 48,2\% dan dibulatkan menjadi 48\%. Artinya sumbangan variabel profesionalitas tenaga pendidik terhadap variabel kinerja mutu pendidikan di Madrasah Aliyah Negeri 1 Pekanbaru sebesar 48\%, sedangkan sisanya dipengaruh oleh variabel lain yang tidak dijelaskan di penelitian ini. Maka dengan adanya tenaga pendidik yang profesional akan dapat meningkatkan mutu pendidikan.

\section{Kata Kunci: Korelasional, Profesionalitas Tenaga Pendidik dan Mutu Pendidikan.}

\section{A. PENDAHULUAN}

Pendidikan adalah usaha sadar dan terencana untuk mewujudkan suasana belajar dan proses pembelajaran agar peserta didik aktif mengembangkan potensi dirinya untuk kekuatan spritual keagamaan, pengendalian diri, kepribadian, kecerdasan, akhlak mulia serta keterampilan yang diperlukan dirinya, masyarakat, bangsa dan negara ${ }^{1}$ sebagaimana tercantum dalam Undang-undang Sistem Pendidikan Nasional.

Sesuai dengan pengertian di atas maka dirumuskanlah tujuan pendidikan nasional sebagaimana yang tercantum dalam Undang-undang Sisdiknas, yaitu: untuk mengembangkan potensi peserta didik agar menjadi manusia yang beriman dan bertakwa kepada Tuhan Yang Maha Esa, berakhlak mulia, sehat, berilmu, cakap, kreatif, mandiri, dan menjadi warga negara yang demokratis serta bertanggung jawab. ${ }^{2}$ Untuk dapat merealisasikan tujuan pendidikan nasional tersebut diperlukan adanya pendidikan yang bermutu.

Pendidikan menjadi modal utama dan salah satu pilar dalam menyongsong dan megantisipasi kehidupan dimasa yang akan datang, karena orientasi dari pendidikan ini adalah untuk mengembangkan sumber daya peserta didik yang berguna dan berperan penting dimasa yang akan datang sesuai dengan perkembangan zaman. Sehubungan dengan itu pendidikan memegang peran utama untuk mencerdaskan sumber daya manusia di Indonesia.

\footnotetext{
${ }^{1}$ Undang-Undang Nomor 20 Tahun 2003 Tentang Sistem Pendidikan Nasional Bab 1 Pasal 1 Ayat (1)

${ }^{2}$ Undang-Undang Nomor 20 Tahun 2003 Tentang Sistem Pendidikan Nasionla, Bab II Pasal 3
} 
ISTIGHNA, Vol. 3, No 2, Juli 2020 P-ISSN 1979-2824

Homepage: http://e-journal.stit-islamic-village.ac.id/index.php/istighna

Siti Aisyah, Rini Setyaningsih Hubungan antara Profesionalitas Tenaga Pendidik dengan Mutu Pendidikan di Madrasah Aliyah Negeri 1 Pekanbaru

Pendidikan bermutu adalah pendidikan yang bisa bahkan mampu melakukan sebuah proses yang menunjukkan kualitas peserta didik dan diaplikasikan dengan cara membebaskan peserta didik dari buruknya akhlak dan keimanan, ketidakmampuan, ketidaktahuan, ketidakjujuran, dan ketidakberdayaan. ${ }^{3}$

Pendidikan bermutu lahir dari adanya suatu perencanaan sistem yang baik (good planning system), dengan sistem dan materi tata kelola yang baik (good govermance system), dan penyampaian yang baik oleh tenaga pendidik (good teachers) dengan komponen pendidikan yang bermutu, khususnya tenaga pendidik. ${ }^{4}$ Tenaga pendidik dikatakan sebagai tenaga pendidik yang bermutu jika ia menguasai metodologi, materi ajar, psikologi belajar dan sistem evaluasi.

Pendidikan yang bermutu dapat dilihat dengan menelaah mutu dan dilihat dari segi proses. Dari segi proses mutu pendidikan adanya faktor yang berperan secara efektif dan efisiensi dalam proses pendidikan. Faktor-faktor tersebut adalah: kurikulum yang dilaksanakan, suasana belajar, sarana dan prasarana, kualitas tenaga pendidik dan pengelolaan sekolah. ${ }^{5}$

Mutu pendidikan dapat dilihat dari lima macam penilaian, yaitu sebagai berikut: ${ }^{6}$

1. Prestasi peserta didik yang dihubungkan dengan norma nasional dan agama dengan menggunkaan skala nilai

2. Kualitas belajar mengajar

3. Kualitas mengajar

4. Kinerja sekolah

Tenaga pendidik dalam sebuah lembaga pendidikan merupakan salah satu kunci keberhasilan dari pendidikan itu sendiri, tenaga pendidik juga merupakan agen dari lembaga pendidikan, baik buruknya prestasi lembaga pendidikan tidak lepas dari peran seorang tenaga pendidik.

Guru adalah tenaga pendidik profesional dengan tugas utama mendidik, mengajar, membimbing, mengarahkan, melatih, menilai, dan mengevaluasi peserta didik pada pendidikan anak usia dini, jalur pendidikan formal, pendidikan dasar, dan pendidikan menengah. Selanjutnya pada ayat 4 dijelaskan bahwa profesional adalah pekerjaan atau kegiatan yang dilakukan oleh seseorang dan menjadi sumber penghasilan kehidupan yang memerlukan keahlian, kemahiran atau kecakapan yang memenuhi standar mutu atau norma tertentu serta memerlukan pendidikan profesi. ${ }^{7}$ Hal ini tercantum dalam undang-undang nomor 14 Tentang Guru dan Dosen.

\footnotetext{
3 Dedi Mulyasa, Pendidikan Bermutu dan Berdaya Saing, (Bandung: PT. Remaja Rosdakarya, 2012), hlm. 119

${ }^{4}$ Ibid,.

${ }^{5}$ Nur Zazin, Gerakan Menata Mutu Pendidikan Teori dan Aplikasi,(Jogjakarta: Ar-Ruzz Media, 2011), hlm. 66

6 Ibid,.

${ }^{7}$ Undang-undang Nomor 14 tahun 2005 Tentang Guru dan Dosen Pasal 1 ayat (4)
} 
ISTIGHNA, Vol. 3, No 2, Juli 2020 P-ISSN 1979-2824

Homepage: http://e-journal.stit-islamic-village.ac.id/index.php/istighna

Siti Aisyah, Rini Setyaningsih Hubungan antara Profesionalitas Tenaga Pendidik dengan Mutu Pendidikan di Madrasah Aliyah Negeri 1 Pekanbaru

Sebagai seorang profesional tenaga pendidik harus memiliki kompetensi ketenaga pendidikan yang baik, kompetensi ketenaga pendidikan akan terlihat pada kemampuan tenaga pendidik dalam menerapkan sejumlah konsep, asas kerja sebagai tenaga pendidik, mampu mendemonstrasikan sejumlah strategi maupun pendekatan pengajaran yang menarik dan interaktif, disiplin, jujur dan konsisten. Pendidik profesional wajib memiliki kualifikasi akademik, kompetensi, sertifikat pendidik, sehat jasmani dan rohani, serta memiliki kemampuan untuk mewujudkan tujuan pendidikan nasional. ${ }^{8}$

Pendidik yang profesional akan mampu memulai proses pembelajaran dengan menggunakan strategi dan berbagai macam metode pembelajaran yang bermacam-macam, sehingga menjadikan proses dari pembelajaran berjalan dengan lancar dan serta menjadikan suasana pembelajaran yang menyenangkan. Pendidik profesional diharapkan mampu mewujudkan tujuan pembelajaran dengan efektif dan efisien.

Tuntutan tenaga pendidik bukan hanya menguasai kemampuan dalam mengajar dan pengajaran saja, tetapi seorang tenaga pendidik harus menguasai kemampuan lainnya yakni memiliki 4 kompetensi tenaga pendidik sebagai berikut, kompetensi profesional, kompetensi kepribadian, kompetensi pedagogik, dan kompetensi sosial sehingga mampu membuat peserta didik tertarik dan memperhatikan seorang guru dalam proses pembelajaran. Untuk menjawab tuntutan tenaga pendidik diatas maka diperlukan tenaga pendidik yang profesional. Maka dari itu seorang tenaga pendidik dituntut tidak hanya untuk menciptakan suasana belajar yang kondusif di dalam kelas saja, tetapi juga tenaga pendidik harus mampu melahirkan anak bangsa yang cerdas, demokratis, inovatif, kritis, dan berakhlak mulia. Dalam mewujudkan cita-cita mulia, yakni mencerdaskan kehidupan bangsa dibutuhkan Seorang tenaga pendidik yang profesional dan bermartabat.

Namun, salah satu permasalahan pendidikan yang dihadapi oleh bangsa Indonesia adalah mutu pembelajaran yang rendah pada setiap jenjang dan satuan pendidikan, khususnya pendidikan dasar dan menengah. Rendahnya mutu pembelajaran tentu sangat erat kaitannya dengan mutu pendidikan yang ada disebuah sekolah. Rendahnya mutu pendidikan ini tentu salah satunya dipengaruhi oleh kualitas dari seorang tenaga pendidik, karena pendidik adalah ujung tombak dari sebuah proses pembelajaran di sekolah.

Adapaun beberapa penelitian yang relevan dari penelitian ini adalah : (a) Upaya tenaga pendidik dalam Meningkatkan Mutu Pendidikan di MIN 7 Blitar oleh Fransiska Dwi Wahyuni (2018), (b) Hubungan Profesionalisme tenaga pendidik Dengan Kemampuan Mengajar Di SDN Selapanjang Jaya 2 Nelegasi Kota

\footnotetext{
${ }^{8}$ Undang-Undang Nomor 14 Tahun 2005 Tentang Guru Dan Dosen Pasal 8 dan 10
} 
ISTIGHNA, Vol. 3, No 2, Juli 2020 P-ISSN 1979-2824

Homepage: http://e-journal.stit-islamic-village.ac.id/index.php/istighna

Siti Aisyah, Rini Setyaningsih Hubungan antara Profesionalitas Tenaga Pendidik dengan Mutu Pendidikan di Madrasah Aliyah Negeri 1 Pekanbaru

Tanggerang oleh Nur Hadi (2012), (c) Pengaruh Kompetensi Profesional tenaga pendidik dalam meningkatkan mutu pembelajaran di SMPN 03 Tangerang Selatan oleh Andi Dwi Puspita Sari (2015), (d) judul Pengaruh Profesionalitas tenaga pendidik Mata Pelajaran Produktif dan Karakteristik Siswa Terhadap Prestasi Belajar Siswa Jurusan Teknik Bangunan SMK Negeri 2 Yokyakarta, oleh Taufiana C. Muna (2012).

Tujuan dari penelitian ini adalah untuk mengetahui: (a) profesionalitas tenaga pendidik, (b) bagaimana mutu pendidikan, (c) bagaimana hubungan antara profesionalitas tenaga pendidik dengan mutu pendidikan di MAN 1 Pekanbaru.

\section{B. METODE PENELITIAN}

Penelitian ini termasuk jenis penelitian kuantitatif dengan menggunakan metode korelasional. Penelitian korelasi berkaitan dengan pengumpulan data untuk mengetahui hubungan antara variabel. ${ }^{9}$ Adapun variabel independen pada penelitian ini adalah profesionalitas tenaga pendidik, sedangkan variabel dependennya yaitu mutu pendidikan. Penelitian ini dilakukan di Madrasah Aliyah Negeri 1 Pekanbaru. Penelitian ini dilakukan setelah melaksanakan seminar proposal, mulai bulan Desember 2019-Februari 2020.

Subjek penelitian ini adalah tenaga pendidik, sedangkan objek dari penelitian ini adalah hubungan antara profesionalitas tenaga pendidik dengan mutu pendidikan di Madrasah Aliyah Negeri 1 Pekanbaru. Populasi penelitian ini adalah tenaga pendidik yang ada di MAN 1 Pekanbaru. Teknik penarikan sampel yang dipilih penulis dalam meneliti hubungan profesionalitas tenaga pendidik dengan mutu pendidikan adalah Sampling Purposive. Sampling Purposive adalah teknik penentuan sampel dengan pertimbangan tertentu. ${ }^{10}$ Sampel yang peneliti ambil adalah tenaga pendidik di MAN 1 Pekanbaru dengan pertimbangan sudah memenuhi kriteria tenaga pendidik yang sudah profesional, meliputi: kualifikasi akademik, kompetensi pendidik dan sertifikat pendidik yang berjumlah 48 tenaga pendidik dari total 103 tenaga pendidik. Teknik pengumpupan data yang digubakan yakni angket dengan skala likert dan dokumentasi.

\section{Uji Validitas}

Validitas adalah derajat ketepatan antara data yang terjadi pada objek penelitian dengan data yang dapat dilaporkan oleh peneliti. Instrumen yang dinyatakan valid berarti alat ukur tersebut dapat digunakan untuk mendapatkan (mengukur) data yang valid. . ${ }^{11}$ Penulis melakukan uji coba untuk menentukan validitas angket kepada 30 responden tenaga pendidik

9 Syofian Siregar, Metode Penelitian Kuantitatif: Dilengkapi dengan Perbandingan Perhitungan Manual SPSS, (Jakarta: Kencana, 2013), hlm. 250

${ }^{10}$ Sugiono, Ibid, hlm. 85

${ }^{11}$ Sugiyono, op.Cit., hlm. 363-364. 
ISTIGHNA, Vol. 3, No 2, Juli 2020 P-ISSN 1979-2824

Homepage: http://e-journal.stit-islamic-village.ac.id/index.php/istighna

Siti Aisyah, Rini Setyaningsih Hubungan antara Profesionalitas Tenaga Pendidik dengan Mutu Pendidikan di Madrasah Aliyah Negeri 1 Pekanbaru

secara acak dari SMKN 2, MA Muhamadiyah dan SMKN 7 Pekanbaru. Untuk variabel X (Profesionalitas Tenaga Pendidi) Terdapat 30 butir. Setelah uji validitas terdapat 9 butir pernyataan yang tidak valid. sedangkan variabel Y (Mutu Pendidikan) terdapat 25 item. Setelah uji validitas terdapat 3 item yang tidak valid.

\section{Uji Realibilitas}

Uji reliabilitas angket dilakukan dengan menggunaan teknik korelasi alpha cronbach dengan bantuan program SPSS 18 untuk mengetahui reliabilitas instrument angket. Instrumen dikatakan reliabel jika alat ukur tersebut menunjukkan hasil yang konsisten, sehingga instrumen tersebut dapat digunakan secara aman karena dapat bekerja dengan baik pada waktu dan kondisi yang berbeda. Dengan ketentuan nilai cronbach alpha minimal 0,6 artinya jika hasil perhitungan lebih besar dari 0,6 maka disimpulkan kuisioner tersebut reliable, sebaliknya jika cronbach alpha lebih kecil dari 0,6 maka disimpulkan tidak reliabel.

Berdasarkan hasil perhitungan menggunakan SPSS 18 didapatkan hasil untuk variabel X nilai koefesien alpha hitung (Cronbach Alpha) sebesar 0,815 lebih besar dari 0,60. Sedangkan variabel Y didapatkan hasil nilai koefesien alpha hitung (Cronbach Alpha) sebesar 0,887 lebih besar dari 0,60. Maka disimpulakn intrument angket variabel $\mathrm{X}$ dan $\mathrm{Y}$ bersifat reliabel.

\section{Uji Normalitas}

Uji normalitas data dilakukan bertujuan untuk mengetahui apakah data penelitian berdistribusi normal atau tidak. Uji normalitas dilakukan menggunakan bantuan program SPSS 18. Cara yang digunakan untuk mengetahui normal atau tidaknya ialah apabila nilai signifikansi lebih besar dari 0.05 ( sig > 0.05) maka dapat disimpulkan data berdistribusi normal dan jika nilai signifikansi lebih kecil dari 0.05 (sig < 0.05), maka data tidak berdistribusi normal. Berdasarkan hasil uji pada program SPSS 18 didapatkan hasil nilai signifikansi sebesar 0.186 lebih besar dari 0.05 (0.186>0.05). Jadi dapat disimpulkan bahwa data penelitian berdistibusi normal.

\section{Uji Linearitas}

Uji linieritas bertujuan untuk mengetahui apakah dua variabel mempunyai hubungan yang linier atau tidak secara signifikan. Uji linieritas dilakukan dengan pengujian pada SPSS dengan menggunakan test for linearity pada taraf signifikan 0,05 Dua variabel dikatakan mempunyai hubungan yang linear bila signifikansi (linearity) kurang dari 0,05. Berdasarkan hasil uji didapatkan nilai nilai signifikansi $=0,000$ lebih kecil dari 0,05, karena signifikasi kurang dari 0,05 maka dapat disimpulkan bahwa antara variabel profesionalitas tenaga pendidik dan mutu pendidikan dapat hubungan linear secara signifikan. 
ISTIGHNA, Vol. 3, No 2, Juli 2020 P-ISSN 1979-2824

Homepage: http://e-journal.stit-islamic-village.ac.id/index.php/istighna

Siti Aisyah, Rini Setyaningsih Hubungan antara Profesionalitas Tenaga Pendidik dengan Mutu Pendidikan di Madrasah Aliyah Negeri 1 Pekanbaru

\section{HASIL DAN PEMBAHASAN}

Rekapitulasi angket tentang profesionalitas tenaga pendidik di Madrasah Aliyah Negeri 1 Pekanbaru diketahui bahwa alternatif jawaban:

1. Selalu dengan skor 5 dipilih sebanyak 517 kali

2. Sering dengan skor 4 dipilih sebanyak 385 kali

3. Kadang-kadang dengan skor 3 terpilih sebanyak 61 kali

4. Jarang dengan skor 2 terpilih sebanyak 0 kali

5. Tidak Pernah dengan skor 1 terpilih sebanyak 3 kali

Jumlah pilihan pada angket variabel profesionalitas tenaga pendidik berjumlah 966. Jumlah pilihan pada angket variabel profesionalitas tenaga pendidik berjumlah 966. Tahapan selanjutnya jumlah pada setiap pilihan alternatif jawaban dikalikan dengan skor nilai masing-masing jawaban. Adapun hasil alternatif jawaban yang diperoleh sebagai berikut:
1. Selalu
$5 \times 517=2585$
2. Sering
$4 \times 385=1540$
3. Kadang-kadang
$3 \times 61$
$=183$
4. Jarang
$2 \times 0=0$
5. Tidak Pernah
$1 \times 3$
$=3+$
Jumlah
(F) $=4311$

Kemudian, jumlah seluruh pilihan dikalikan dengan bobot jawaban tertinggi yaitu: 966 x $5=4830$ (N). Dari hasi tersebut, unsur F dan N sudah diketahui, selanjutnya, hasil tersebut distribusikan ke dalam rumus sebagai berikut:

$$
\begin{aligned}
& \mathrm{P}=\frac{F}{N} \times 100 \% \\
& \mathrm{P}=\frac{4311}{4830} \times 100 \% \\
& \mathrm{P}=89,25 \%
\end{aligned}
$$

Berdasarkan kategori diatas, diketahui bahwa angka atau skor $89 \%$ berada pada rentang $81 \%$ - 100\%. Maka dapat disimpulkan bahwa Profesionalitas Tenaga Pendidik di MAN 1 Pekanbaru berada pada kategori "Sangat Baik".

Untuk menganalisis data Mutu Pendidikan di MAN 1 Pekanbaru, rekapitulasi angket mutu pendidikan diketahui bahwa alternatif jawaban:

1. Selalu terpilih sebanyak 481 kali

2. Sering terpilih sebanyak 482 kali 
ISTIGHNA, Vol. 3, No 2, Juli 2020 P-ISSN 1979-2824

Homepage: http://e-journal.stit-islamic-village.ac.id/index.php/istighna

Siti Aisyah, Rini Setyaningsih Hubungan antara Profesionalitas Tenaga Pendidik dengan Mutu Pendidikan di Madrasah Aliyah Negeri 1 Pekanbaru

3. Kadang-kadang terpilih sebanyak 45 kali

4. Jarang terpilih sebanyak 4 kali

5. Tidak Pernah terpilih sebanyak 0 kali

Jumlah pilihan pada angket mutu pendidikan seluruhnya berjumlah adalah 1012. Selanjutnya jumlah setiap pilihan alternatif jawaban dikalikan dengan skor nilai masing-masing jawaban. Adapun hasil alternatif jawaban yang diperoleh sebagai berikut:

\begin{tabular}{|c|c|c|}
\hline Sering & $5 \times 481$ & $=2.405$ \\
\hline Selalu & $4 \times 482$ & $=1.928$ \\
\hline Kadang-kadang & $3 \times 45$ & $=135$ \\
\hline Jarang & $2 \times 4$ & $=8$ \\
\hline Tidak Pernah & $1 \times 0$ & $=0+$ \\
\hline Jumlah & $(\mathrm{F})$ & $=4476$ \\
\hline
\end{tabular}

Kemudian jumlah seluruh pilihan dikalikan dengan bobot tertinggi 1012 x 5 $=5060(\mathrm{~N})$. Dari hasil tersebut unsur $\mathrm{F}$ dan $\mathrm{N}$ sudah diketahui, selanjutnya distribusikan k edalam rumus sebagai berikut:

$$
\begin{aligned}
& \mathrm{P}=\frac{F}{N} \times 100 \% \\
& \mathrm{P}=\frac{4476}{5060} \times 100 \% \\
& \mathrm{P}=88,45 \%
\end{aligned}
$$

Berdasarkan kategori diatas, diketahui bahwa angka atau skor $88 \%$ berada pada rentang $81 \%$ - 100\%. Maka dapat disimpulkan bahwa mutu pendidikan di MAN 1 Pekanbaru berada pada kategori "Sangat Baik".

\section{Uji korelasi Hubungan Antara Profesionalitas Tenaga Pendidik dengan Mutu Pendidikan di Madrasah Aliyah Negeri 1 Pekanbaru}

Untuk mengetahui korelasi hubungan profesionalitas tenaga pendidik dengan mutu pendidikan dianalisis dengan menggunakan teknik korelasi Product Moment Pearson dengan rumus sebagai berikut:

$$
\begin{aligned}
\mathrm{r}_{\mathrm{xy}} & =\frac{n \sum X Y-\sum X-\sum Y}{\sqrt{n \sum X^{2}}-\left(\sum X\right)^{2} \sqrt{n \sum Y^{2}-\left(\sum Y\right)^{2}}} \\
\mathrm{r}_{\mathrm{xy}} & =\frac{46(420663)-(4311)(4475)}{\sqrt{\left[46(405987)-(4311)^{2}\right]\left[46(437059)-\left(4475^{2}\right)\right]}} \\
\mathrm{r}_{\mathrm{xy}} & =\frac{19350498-19291725}{\sqrt{[90681][79089]}}
\end{aligned}
$$


ISTIGHNA, Vol. 3, No 2, Juli 2020 P-ISSN 1979-2824

Homepage: http://e-journal.stit-islamic-village.ac.id/index.php/istighna

Siti Aisyah, Rini Setyaningsih Hubungan antara Profesionalitas Tenaga Pendidik dengan Mutu Pendidikan di Madrasah Aliyah Negeri 1 Pekanbaru

$$
\begin{array}{ll}
r_{x y} & =\frac{58773}{\sqrt{7171869609}} \\
r_{x y} & =\frac{58773}{84686,8916} \\
r_{x y} & =0,694004
\end{array}
$$

Berdasarkan data di atas maka dapat disimpulkan bahwa besar korelasi profesionalitas tenaga pendidik dengan mutu pendidikan adalah 0,694, yaitu terletak antara $0.60-0.80$, yang berarti korelasi dianggap kuat atau tinggi, maka diperoleh rxy $=0.409 \geq 0,2159$ rtable pada taraf singnifikan 5\%, artinya H0 ditolak dan Ha diterima. Jadi dapat disimpulkan terdapat korelasi positif yang signifikan antara profesionalitas tenaga pendidik dengan mutu pendidikan di Madrasah Aliyah Negeri 1 Pekanbaru. Karena koefisien korelasinya positif maka dapat disimpulkan bahwa semakin tinggi profesionalitas tenaga pendidik maka tinggi pula mutu pendidikan di Madrasah Aliyah Negeri 1 Pekanbaru.

Selanjutnya adalah pengujian signifikan korelasi profesionalitas tenaga pendidik dengan mutu pendidikan di MAN 1 Pekanbaru. Hipotesis yang diuji adalah:

1. Ho: Tidak ada hubungan yang positif dan signifikan antara profesionalitas tenaga pendidik dengan mutu pendidikan di Madrasah Aliyah Negeri 1 pekanbaru.

2. Ha: Adanya hubungan yang signifikan antara profesionalitas tenaga pendidik dengan mutu pendidikan di Madrasah Aliyah Negeri 1 Pekanbaru.

Untuk mengetahui korelasi antara variabel $\mathrm{X}$ dan $\mathrm{Y}$ pengujian hipotesis dilakukan dengan mengetahui korelasi antara variabel tersebut dengan menggunakan koefisien korelasi product moment pearson. Dengan program SPSS menggunakan fasilitas analisis regresi. Output yang dibutuhkan adalah tabel correlation dan tabel coefisien. Dengan taraf signifikan $\alpha=5 \%$ (umumnya menggunakan tingkat kepercayaan 95\%) dengan ketentuan:

1. Nilai sig. atau probabilitas kecil dari 0.05 ( $\mathrm{sig}<0.05$ ) artinya terdapat pengaruh yang signifikan.

2. Nilai sig. atau probabilitas lebih besar dari 0.05 (sig > 0.05) artinya tidak terdapat pengaruh yang signifikan.

Berdasarkan table analisis, diperoleh koefisien korelasi pengaruh profesionalitas tenaga pendidik dengan mutu pendidikan adalah sebesar $(r)=0.694$ disertai signifikan 0.000 oleh karena probabilitas lebih kecil dari maka H0 ditolak, artinya Ha diterima yaitu terdapat hubungan yang positif dan signifikan antara profesionalitas tenaga pendidik dengan mutu pendidikan di MAN 1 Pekanbaru. Dengan kata lain semakin tinggi tingkat profesionalitas tenaga pendidik maka semakin tinggi pula tingkat mutu pendidikan di MAN 1 Pekanbaru. 
ISTIGHNA, Vol. 3, No 2, Juli 2020 P-ISSN 1979-2824

Homepage: http://e-journal.stit-islamic-village.ac.id/index.php/istighna

Siti Aisyah, Rini Setyaningsih Hubungan antara Profesionalitas Tenaga Pendidik dengan Mutu Pendidikan di Madrasah Aliyah Negeri 1 Pekanbaru

\section{KESIMPULAN}

Berdasarkan penelitian dan analisis data dengan judul hubungan antara profesionalitas tenaga pendidik dengan mutu pedidikan di Madrasah Aliyah Neger 1 Pekanbaru, dan telah penulis sajikan pada pembahasana terdahulu, maka dapat ditarik kesimpulan:

1. Tingkat profesionalitas tenaga pendidik di Madrasah Aliyah Negeri 1 berdasarkan penelitian yang penulis lakukan berada pada angka atau skor 89, $25 \%$ dan pada rentang 81\%-100\%. Maka dapat disimpulkan bahwa profesionalitas tenaga pendidik di Madrasah Aliyah Negeri 1 Pekanbaru berada pada pada kategori "Sangat Baik".

2. Tingkat Mutu Pendidikan di Madrasah Aliyah Negeri 1 Pekanbaru berada pada angka atau skor $88,45 \%$ dan berada pada rentang rentang $81 \%-100 \%$. Maka dapat disimpulkan bahwa Tingkat mutu pendidikan di Madrasah Aliayah Negeri 1 Pekanbaru berada pada pada kategori "Sangat Baik".

3. Terdapat korelasi yang positif dan signifikan antara profesionalitas tenaga pendidik dengan mutu pendidikan di Madrasah Aliyah Negeri 1 Pekanbaru. Tingkat pengaruh variabel $\mathrm{X}$ dan $\mathrm{Y}$ berada pada kategori kuat atau tinggi dengan nilai $\mathrm{r}$ sbesar 0.694 , sedangkan koefisien determinasi $\mathrm{R}$ (square) adalah 48,2\%. Jadi kontribusi variabel profesionalitas tenaga pendidik dengan mutu pedidikan sebesar $48 \%$ dan sisanya dipengaruhi oleh faktor lain.

\section{REFERENSI}

Abdullah, Ridwan Sani, Isda Pramuniati dan Anies Mucktiany.2015. Penjaminan Mutu Sekolah. Jakarta: Bumi Aksara

Aedi, Nur. 2016. Manajemen Pendidik dan Tenaga Pendidikan. Yogyakarta: Gosyen Publishing

Barnawi \& M. Arifin. 2017. Sistem Penjaminan Mutu Pendidikan, Teori dan Praktek. Jakarta: Ar Ruz Media

Danim, Sudarwan. 2013. Profesionalisasi dan Etika Profesi Guru. Bandung: Alfabeta

Hadis, Abdul dan Nurhayati B. 2012. Manajemen Mutu Pendidikan. Bandung: Alfabeta

Hanafi, Halid. La Adu, \& H. Muzakkir. 2018. Profesionalitas Guru dalam Pengelolaan kegiatan Pembelajaran di Sekolah. Yogyakarta: Deepublish

Husein, Latifah. 2017. Profesi Ketenaga pendidikan. Menjadi Guru Profesional. Yogyakarta: Pustaka Baru Press 
ISTIGHNA, Vol. 3, No 2, Juli 2020 P-ISSN 1979-2824

Homepage: http://e-journal.stit-islamic-village.ac.id/index.php/istighna

Siti Aisyah, Rini Setyaningsih Hubungan antara Profesionalitas Tenaga Pendidik dengan Mutu Pendidikan di Madrasah Aliyah Negeri 1 Pekanbaru

Mulyasa, Dedi. 2012. Pendidikan Bermutu dan Berdaya Saing. Bandung: PT.Remaja Rosdakarya

Musfah, Jejen. 2011. Peningkatan Komptensi Guru, Melalui Pelatihan dan Sumber Belajar Teoritik dan Praktik. Jakarta: Kencana Prenada Media Grup

Rizali, Ahmad, Indra Djati sidi, Satria Dharma. 2009. Dari Guru Konvensional Menunju Guru Profesional. Jakarta: PT. Grasindo

Sagala, Syaiful. Kemampuan Profesional Guru dan Tenaga kependidikan, Bandung: Alfabeta

Suprihatiningrum, Jamil. 2013. Guru Profesional, Pedoman Kinerja, Kualifikasi dan Kompetensi Guru. Jogyakarta: Ar-Ruzz Media

Syofian, Siregar. 2013. Metode Penelitian Kuantitatif: Dilengkapi dengan Perbandingan Perhitungan Manual SPSS. Jakarta: Kencana

Suyanto dan Asep Jihad. 2013. Menjadi Guru Profesional, Strategi Meningkatkan Kualifikasi dan Kualitas Guru di Era Global. Jakarta: Erlangga

Undang-Undag Nomor 20 Tahun 2003 Tentang Sistem Pendidikan Nasional Bab 1 Pasal 1 Ayat (1)

Undang-undang Nomor 14 tahun 2005 Tentang Guru dan Dosen Pasal 1 ayat (4)

Zazin, Nur. 2011. Gerakan Menata Mutu Pendidikan Teori dan Aplikasi. Jogjakarta: Ar-Ruzz Media

Aziz, Amrullah.2015. Peningkatan Mutu Pendidikan. Jurnal Studi Islam, Vol. 10. No. 2

Yusutira. 2017. Profesionalitas Guru dalam Meningktakan Kualitas Sumber Daya Manusia, Jurnal Curicula, Vol. 2. No. 1 